\title{
E-MAN... (A HAND CUM LEG INSTRUMENT). FOR THE AMPUTEES OF THIS UNIVERSE -DIFFERENTLY ABLED TO DEFINITELY ABLED.
}

\author{
Rajiv A ${ }^{1 *}$ Lakshmi $^{1}$ Divya $\mathrm{M}^{2}$ \\ ${ }^{1}$ Assistant Professor, ECE Sriram Engineering College, Perumalpattu -602 024 \\ ${ }^{2}$ Research Associate, Vellore Institute of Technology, Chennai \\ rajiva.ece@sriramec.edu.in,lakshmic.ece@sriramec.edu.in,divyamanne16@gmail.com
}

\begin{abstract}
Necessity is the mother of all inventions. Brain-The Master of our body generates signals in accord with our thoughts and decrees every part to perform the desired actions. This paper is a boon to the amputees (those who lost their both legs and hands). Our main objective of this paper is to make the amputees to do some of the works as like normal human beings and also to do some extra works that even a normal man cannot able to do that with his normal hands and legs. This paper targets in trapping the signals by the use of EPOC NEURO HEADSET (A 14 Electrode Headset Can Detect Facial Gestures, And It's Built In Gyroscope Detects Head Movements, Which Is Attached To The Scalp In Order To Monitor The Brain Wave Activity In Different Parts Of The Brain) and feed the signals to the so designed artificial hands. This proposed system is different from the already existing ones. It can encompass activities like peeling; lifting heavier objects, and also feel things as our normal human hand. it can lift the whole weight of its own body. The existing models can provide only support but the proposed prototype for this paper can respond to External Stimulus and performs all the actions with only by means of the brain signals, and can do major activities using our brain and brain computer interface, without depending on others.
\end{abstract}

\section{INTRODUCTION}

The Brain waves which are obtained from device called EPOC (EEG) Waves (Electro Encephalo Gram). show us the brain's response to an external stimulus or event and the actions that a human performs. Brain activity before, during, and after a stimulus presentation is recorded. This allows us to observe where, when, and how the brain responds to a given stimulus.

In the existing systems people are given an external attachment of an artificial hand which gives a look similar to that of a normal hand though cannot perform all the desired actions. The existing models cannot stimulate actions as per our thought. In the proposed system the signals are directly obtained from the brain without any pre existing sensor for this purpose. The problems faced by the amputees are also increasing day by day and hence proposed prototype is a panacea for all such problems faced by them to a greater extent.

\section{MAIN PRINCIPLE:}

Using electrical impulses, they send messages to and through each other. Whenever your brain is working (and that means always, even during sleep), all these messages firing from neuron to neuron amount to an electrical current. The Changes in the electric fluctuation which results in billions of active neurons inside the brain interacting with each other and chemical reaction just mixes electric Impulse. 


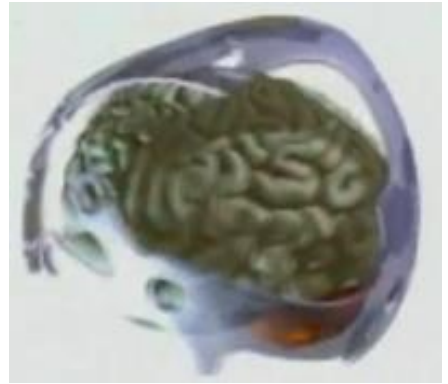

Because of its inherent differences in the folding of structure across the populations, it individualize much like a finger print so from signal point of view looking at the electrical signal even though it comes from the same source steep inside the brain by the time it travels through the cortex, it gets bounced by the various folding structure and gets projected on the surface of the scalp to be measured by the non invasive sensors

\section{B.COMPONENTS USED: EPOC HEADSET:}

The EPOC headset was designed by emotive systems in conjunction with Sydney based industrial consultancy for design.

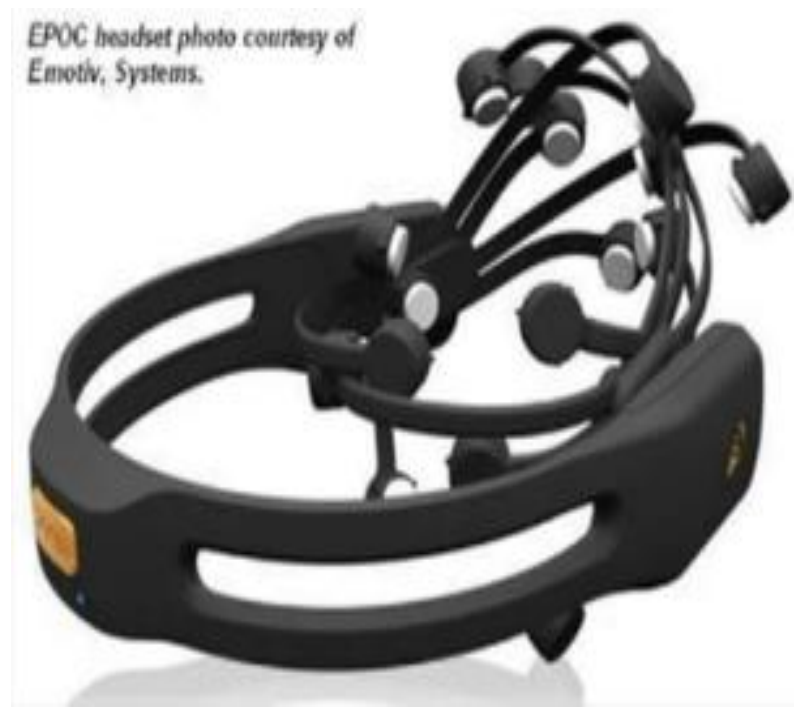

It has fourteen electrodes compared with a nineteen electrode of standard medical EEG
It can measure four types of inputs they are:

$\checkmark$ CONCIOUS THOUGHTS (cognitive Suite):-

Using EPOC, we can perform TWELVE kinds of MOVEMENT, SIX DIRECTIONS and SIX ROTATIONS.

SIX DIRECTIONS: "UP”,

"DOWN",'LEFT",,"RIGHT"

"FORWARD","ZOOM".

SIX ROTATIONS:"ANTI CLOCKWISE

ROTATION",

"TURNLEFT",,"TURNRIGHT",,SWAY

BACKWARD"

"SWAY FORWARD", and in addition to this

"DISAPPEAR".

2. EMOTION (affective suite):-

"EXCITEMENT",

"ENGAGEMENT/BOREDOM",

"MEDITATION","FRUSTATION" can be measured.

3. FACIAL EXPRESSIONS (expressive suite):-

Individual eyelid and eyebrow position in the horizontal plane, smiling, laughing, clenching, smirking can be detected and these are not taken from the brain but from the muscle actions, because it is more fast than taking signal from the brain (10milli seconds).

\section{HEAD ROTATIONS:-}

Angular velocity of one's head can be measured in the Yaw and pitch (but not roll) directions. This is detected by gyros and it is not related to EEG features.

\section{MIND CONTROLLED ARTIFICIAL ROBOTIC HAND:-}

These types of robotic hand are of mind controlled, by using the EPOC headset's directions (6 direction and 6 rotations).

The robotic hand is having a WRIST and BELOW ELBOW and ABOVE ELBOW. These WRIST and 
ABOVE ELBOW, BELOW ELBOW can be REMOVED and FITTED EASILY for ANY NUMBER OF TIMES.

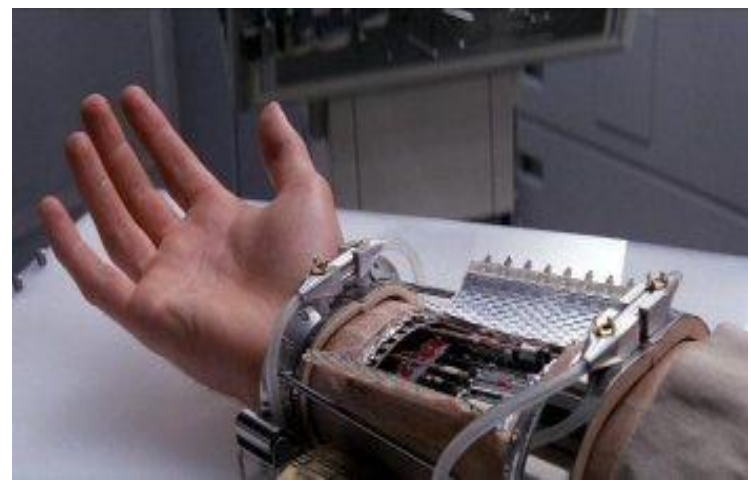

C. WORKING:

\section{THE WORKING OF THIS INSTRUMENT IS} DESIGNED TO WORK IN TWO MODES:

- HAND MODE.

- LEG MODE.

\section{$\checkmark$ HAND MODE:}

CONTROLLING OF ARTIFICIAL HAND (ROBOTIC):

TRANSMITTING SECTION: The signal obtained from the EPOC is converted to the instructions which can be easily understandable by the ARTIFICIAL ROBOTIC hand, by means of Software called ROBOCLIENT.

RECEIVING SECTION: The receiving section is divided in to 3 devices.

1. ARM.

2. FORE ARM.

3. PALM. (with wheels)

\section{CONTROLLING OF HAND:}

At the robotic end the received signals are being transmitted as the action by means of software called as ROBODANCE. The first signal is meant for which device to be in active.

LOOK UP TABLE:

SELECTION OF MODE:

ZOOMING ACTION OF HEAD: LEG MODE.

SHAKING ACTION OF HEAD: HAND MODE

\section{SELECTION OF HAND:}

SWAY BACK: LEFT HAND.

SWAY FORWARD: RIGHT HAND.

ACTIVE PART OF THE SELECTED HAND:

CROSSING EYES (LEFT): ARM.

CROSSING EYES (RIGHT): FORE ARM.

CROSSING OF TWO EYES: PALM.

\begin{tabular}{|c|c|}
\hline USER ACTIONS: & DEVICE ACTIONS: \\
\hline TURNINIG HEAD & MOVING \\
\hline LEFT & $\begin{array}{l}\text { SELECTED HAND TO } \\
\text { THE LEFT. }\end{array}$ \\
\hline TURNING & MOVING \\
\hline RIGHT & $\begin{array}{l}\text { SELECTED HAND TO } \\
\text { THE RIGHT. }\end{array}$ \\
\hline HEAD UP & MOVING \\
\hline & $\begin{array}{l}\text { SELECTED HAND TO } \\
\text { FORWARD. }\end{array}$ \\
\hline MOVING & MOVING \\
\hline DOWN & $\begin{array}{l}\text { SELECTED HAND TO } \\
\text { BACKWARD. }\end{array}$ \\
\hline SMIL & $\begin{array}{l}\text { HALTING THE ACTIVE } \\
\text { DEVICE WORK. }\end{array}$ \\
\hline
\end{tabular}

CONTROLLING OF FINGERS: The finger movements can be controlled by means of selecting the palm of the selected hand and the look up table actions can be performed. 
LOOK UP TABLE:

\begin{tabular}{|c|c|}
\hline USER ACTIONS: & DEVICE ACTIONS: \\
\hline $\begin{array}{l}\text { ROTATING HEAD } \\
\text { CLOCKWISE }\end{array}$ & $\begin{array}{l}\text { HOLDING ANY } \\
\text { OBJECT }\end{array}$ \\
\hline $\begin{array}{l}\text { ROTATING HEAD } \\
\text { ANTI } \\
\text { CLOCKWISE }\end{array}$ & $\begin{array}{l}\text { PLACING } \\
\text { OBJECT }\end{array}$ \\
\hline $\begin{array}{l}\text { TURNING HEAD } \\
\text { LEFT }\end{array}$ & $\begin{array}{lll}\text { LIFTING UP } & \text { THE } \\
\text { OBJECT } & & \\
\end{array}$ \\
\hline $\begin{array}{l}\text { TURNING HEAD } \\
\text { RIGHT }\end{array}$ & $\begin{array}{ll}\text { DROPPING } & \text { THE } \\
\text { OBJECT } & \\
\end{array}$ \\
\hline $\begin{array}{ll}\text { MOVING } & \text { HEAD } \\
\text { UP } & \\
\end{array}$ & $\begin{array}{l}\text { GIVING } \text { HAND } \\
\text { FOR SHAKING }\end{array}$ \\
\hline $\begin{array}{l}\text { MOVING } \\
\text { DOWN }\end{array}$ & SHOWING BYE \\
\hline SMILING & $\begin{array}{l}\text { HALTING THE } \\
\text { ACTIVE DEVICE. }\end{array}$ \\
\hline
\end{tabular}

WORKING: Using the head movements and facial gestures, the direction of the robotic hand can be controlled, swaying back the head, left hand will be gets selected. Similarly, if sway forward right hand will be get selected, after these actions have been identified that will be imitated by an blue avatar accordingly the signal will be sent to the micro controller where the coding for certain actions will be already programmed, and the encoder circuit will encode the signal obtained from the computer according to the actions performed.
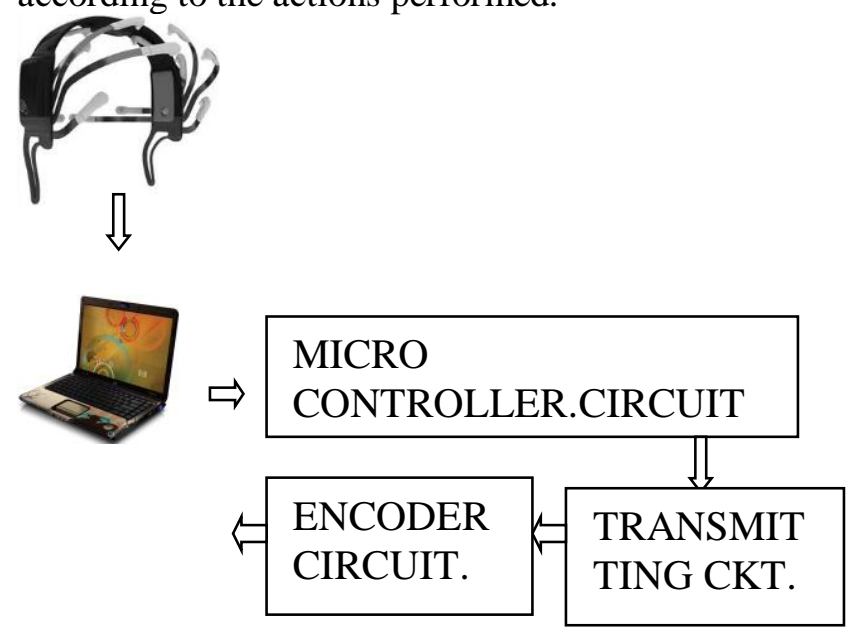

\section{$\checkmark$ LEGMODE(WALKING OPERATION )}

In order to control the instrument as leg proper actions must be performed. And by following the look up table we can perform the actions.

LOOK UP TABLE:

\section{ROTATING CLOCKWISE DIRECTION OF HEAD: OPENING THE WHEELS OF THE INSTRUMENT.}

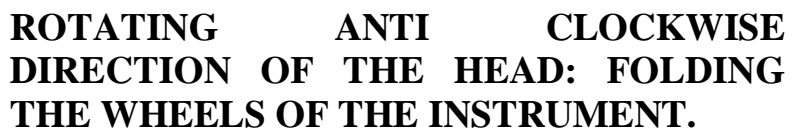

\begin{tabular}{|l|l|}
\hline USER ACTIONS: & DEVICE ACTIONS: \\
\hline TURNING THE & STEPPING THE LEG \\
HEAD LEFT: & FORWARD. \\
\hline TURNING THE & STEPPING THE LEG \\
HEAD RIGHT: & BACKWARD. \\
\hline SMILING: & $\begin{array}{l}\text { HALTS THE ACTIVE } \\
\text { DEVICE. }\end{array}$ \\
\hline
\end{tabular}

\section{OPERATING RANGE:}

The operating range of the proposed system is

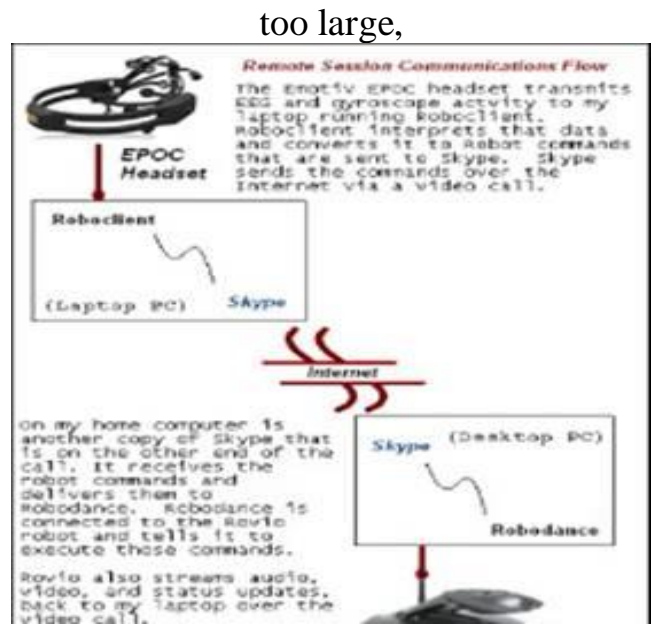

$\sqrt{n}$

www.trendytechjournals.com 
we can control the device sitting form from one country to the other country the obtained brain signals are passed through the microcontroller where these signals are get encoded, and transmitted through the a software called ROBOTCLIENT, via SKYPE as voice call, then these signals are then converted into the robot commands by using the software called ROBOT DANCE and then the device will start to perform its specified action.

\section{PROS:}

- It will be used for the handicapped people who lost their both hands as well as the legs.

- We can do all major actions as like normal human being.

- Effort will be less.

- Easy picking of any object just by thinking

- It can be used in the field of industries.

- It can be used for controlling applications also.

\section{References:}

1.http://www.icub.org/

"Electroencephalography." Encyclopedia Britannica

Online Library Edition. (Nov. 21 2008).

http://library.eb.com.proxygsu-

dep1.galileo.usg.edu/eb/article-9032300

2.Bio-medical.com.-'EEG or Electroencephalography'.

Bio-medical.com. (Dec. 1, 2008) http://bio-

medical.com/news_display.cfm?mode=EEG\&newsid=5

3.della Cava, Marco R. "Let video games read your mind with headset." USA TODAY. (Dec. 1, 2008).

http://www.usatoday.com/tech/gaming/2008-08-04-epoc-

headset_N.htm

4.Edwards, Cliff. "Now That's Using Your Head."

BusinessWeek. Aug. 11, 2008.

5.Emotiv Systems. "Emotiv EPOC." Emotiv Systems.

(Dec. 1, 2008). http://www.emotiv.com/INDS_3/inds_3.html

6.Emotiv Systems. "Emotiv Unveils World's First Brain-

Controlled Video Gaming Headset." Emotiv Systems.

Press Release. Feb. 20, 2008. (Dec. 1, 2008).

http://emotiv.com/corporate/3_0/pr/pr021808a.htm 